\title{
ДЕМОГРАФИЧЕСКАЯ И СЕМЕЙНАЯ ПОЛИТИКА В РАЗНЫХ СТРАНАХ: КОНЦЕПТУАЛЬНЫЕ ПОДХОДЫ И ПРАКТИКИ
}

\section{ОЛЬГА ИСУПОВА}

\begin{abstract}
Статья посвящена анализу различных концептуальных подходов к семейной и демографической политике, начиная с периода формирования теоретических оснований воздействия государства на население в ХІХ веке. Исторически семейная политика выросла из демографической, и одновременно является поздним разделом политики соииальной. Этим объясняется большое количество противоречий в ее идеологии в разных странах. В статье описана эволюиия подходов к семейной политике в Европе и США с акиентом на развитии в конце XX века и в первые десятилетия - ХХІ (рождаемость и экономическое развитие, детское и женское образование, репродуктивные права, благосостояние различных возрастных и гендерных групп населения, баланс жизни и труда, реакиия на падение рождаемости ниже уровня простого воспроизводства, этическое восприятие населением «навязывания» людям стандартов рождаемости и др.). Рассмотрены различные типологии систем семейной политики в развитых странах по разным основаниям - многообразие 6 этой области свидетельствует об отсутствии консенсуса и конвергенции, пока ни одна из национальных систем политики не может быть названа однозначно эффективной. Важным для определения идеологии семейной политики в настоящее время является то, обращена ли она к индивиду (и какому именно индивиду) или к семье как общности (и к какой именно форме/формам семьи), как каждая конкретная концепџия решает вопрос о взаимодействии семьи и государства. На примере США показано, как представления о том, что в семейные дела лучше не вмешиваться, постепенно изменялись, появлялись не только отдельные политики, направленные на помощь семьям, но и стремление соответственно изменить законодательство. Всё больще стран, где семейная политика, скорее, идет за социальными изменениями вместо того, чтобы пытаться направить их в заранее заданное русло.
\end{abstract}

Ключевые слова: демографическая политика, семейная политика, рождаемость, благосостояние, семья и государство.

\section{1. ВВЕДЕНИЕ: ДЕМОГРАФИЧЕСКАЯ ПОЛИТИКА ИЛИ ПОЛИТИКА НАРОДОНАСЕЛЕНИЯ}

Понятие «демографическая политика» (demographic policy/population policy) можно определить следующим образом (Madeira 1974: 13): «Демографическая политика является органической интегральной частью набора процедур, специально созданных для того, чтобы влиять на рост и движение населения прямо и косвенно в соответствии с заранее определенными целями».

\footnotetext{
ОЛЬГА ГЕНРИХОВНА ИСУПОВА (oisupova@hse.ru), НАЦИОНАЛЬНЫЙ ИССЛЕДОВАТЕЛЬСКИЙ УНИВЕРСИТЕТ «ВЫСШАЯ ШКОЛА ЭКОНОМИКИ», РОССИЯ.

СТАТЬЯ НАПИСАНА В РАМКАХ ПРОЕКТА 2019 Г. «ДЕМОГРАФИЧЕСКИЕ И МИГРАЦИОННЫЕ ПРОЦЕССЫ В РОССИИ В ИСТОРИЧЕСКОМ И МЕЖДУНАРОДНОМ КОНТЕКСТЕ В СВЕТЕ НОВЫХ МЕТОДОЛОГИЧЕСКИХ ПОДХОДОВ» ПРОГРАММЫ ФУНДАМЕНТАЛЬНЫХ ИССЛЕДОВАНИЙ ВШЭ.
}

СТАТЬЯ ПОСТУПИЛА В РЕДАКЦИЮ В МАЕ 2020 Г. 
Подчеркивается, что эта политика может влиять на соотношение полов и возрастов, паттерны брачности, здоровье и географическое распределение населения внутри страны. То есть она является средством целенаправленного воздействия на поведение мужчин и женщин, влияющего на рождение детей, заключение и расторжение браков, переезды внутри стран и между странами, заботу о здоровье. Впрочем, этот же автор уже тогда, в 1970-е годы, отмечает, что демографическая политика должна быть неотъемлемой частью социальной политики, направленной на благосостояние населения, для которого в первую очередь важен экономический рост.

В настоящее время цели, определенные как демографические и при этом ориентированные именно на рост населения, характерны для политики небольшого числа стран. Заметное место среди них занимает Россия (еще один яркий пример: около полутора десятилетий назад демографические цели упоминались также в связи с введением премии «бэби-бонус» в Австралии). Почему так произошло? Этот вопрос является основным для нашей статьи.

Связь демографического поведения в области рождаемости с социальноэкономическим благополучием семей и большим числом других неявных факторов, а также практически полное отсутствие исторических примеров повышения рождаемости, рассматриваемого как цель политики в каких-либо странах (рост рождаемости иногда происходил, но нельзя было приписать это только применяемым мерам, или он происходил в гораздо меньших объемах, чем было задано при определении целей политики ${ }^{1}$ ) привели к тому, что в основном внимание исследователей оказалось сосредоточенным на семейной политике, нацеленной на улучшение качества жизни семей. Консенсус в настоящее время состоит в том, что рост благосостояния является достойной целью сам по себе, но может косвенно повлиять благоприятно и на репродуктивные намерения людей, и на их осуществление. Это мнение разделяет и автор статьи.

Однако продолжает существовать и сфера, которая называется сейчас политикой населения/народонаселения (population policy). Определение такой политики несколько отличается от политики демографической, прежде всего тем, что она не ставит заранее сформулированных количественных целей и задач по их достижению, а является ответом на ожидаемые изменения в области рождаемости и смертности, и, во вторую очередь, - в области внутренней и международной миграции, которые влияют на численность, возрастной состав и региональное распределение населения (Handbook of Development Economics 2010). Ожидаемые изменения основываются на исследованиях ученых (на эти исследования, а не на волю политиков, в принципе, может опираться и демографическая политика). Иными словами, политику в области народонаселения можно определить как специально сконструированные или модифицированные институциональные установления и/или специальные программы, с помощью которых государство стремится влиять прямо или косвенно на демографические изменения. Этот подход выгодно отличается от предыдущего тем, что, во-первых, опирается на научные исследования, во-вторых, тем, что не ставит в качестве целей достижение очень точных количественных демографических

\footnotetext{
${ }^{1}$ См. исторический обзор в: (Захаров 2017: 195-214).
} 
показателей - там, где речь идет об изменении социальной ситуации через изменение поведения людей и невозможно, и неэтично предписывать точные численные нормы (например, в отношении числа живых детей, рожденных женщинами, или количества лет, которые человек проживет в добром здравии - первое не учитывает наличия у женщин свободы воли и возможных ограничений в области репродуктивного и общего здоровья, второе требовало бы практически магических предсказательных способностей).

Это мнение разделяет и автор статьи.

Однако продолжает существовать и сфера политики населения (population policy). Такая политика стремится дать ответ на ожидаемые изменения в области рождаемости и смертности, и, во вторую очередь, - в области внутренней и международной миграции, которые влияют на численность, возрастной состав и региональное распределение населения (Handbook of Development Economics 2010). Ожидания в отношении изменений основываются на исследованиях ученых- Иными словами, политику в области народонаселения можно определить как специально сконструированные или модифицированные институциональные установления и/или специальные программы, с помощью которых государство стремится влиять прямо или косвенно на демографические изменения. Этот подход в настоящее время, как правило, не ставит в качестве целей достижение очень точных количественных демографических показателей - там, где речь идет об изменении социальной ситуации через изменение поведения людей и невозможно, и неэтично предписывать точные численные нормы (например, в отношении числа детей, рожденных женщинами, или количества лет, которые человек проживет в добром здравии - первое не учитывает наличия у женщин свободы воли и возможных ограничений в области репродуктивного и общего здоровья, второе требовало бы практически магических предсказательных способностей).

Интересна и специфична история использования всех этих терминов в России и СССР - см. раздел 4 настоящей статьи, а более подробно (Елизаров 2017). В СССР изначально и демографическая политика, и политика народонаселения понимались несколько иначе, чем в западной научной традиции, к нынешнему моменту, однако, произошло сближение терминов.

Определение политики населения, приведенное выше, очень общее, в связи с этим контекстное поле возможных интерпретаций оказывается очень широким. Цель политики может быть сформулирована как желаемое привнесение изменений в четко очерченное население, за которое отвечает некое правительство (Demeny 2003). При этом ответственность за потери в динамике смертности чаще всего лежит на политике в области здравоохранения, в рождаемости и миграции - на специальных институтах, занимающихся социальной, семейной и миграционной политикой. Очень часто в контекст включают только (или в основном) рождаемость и миграцию. С другой стороны, политика народонаселения в широком смысле может учитывать множество других аспектов: состав населения по различным демографическим характеристикам, географическое распределение населения, население разных стран и мира в целом может быть интересно не только своим правительствам, особенно в современную глобализованную эпоху. 
Предмет нашего исследования в настоящей статье - исторические изменения в теоретических подходах к семейной политике и политике населения, а основная задача всесторонний сравнительный анализ этих подходов и изменений на основе исторического опыта разных стран в этой области.

\section{2. ИСТОРИЯ И ТЕОРЕТИЧЕСКИЕ ПОДХОДЫ К ПОЛИТИКЕ, (ПОТЕНЦИАЛЬНО) ВЛИЯЮЩЕЙ НА ДЕМОГРАФИЧЕСКОЕ ПОВЕДЕНИЕ}

Исторически правительства издавна проявляли заинтересованность в том, чтобы влиять на численность и состав населения на подчиненных им территориях в желаемом направлении. Обычно это означало, скорее, рост, чем уменьшение населения: большая численность долго казалась связанной с могуществом и благосостоянием. Уже в античности принимались законы, направленные на стимулирование вступления в брак и иногда и иммиграции. Однако обычно правительствам не удавалось повлиять на эти стороны жизни людей в существенной степени, гораздо больше на брачность и рождаемость влияли традиции разных этносов и культурно-религиозных групп. В традиционном обществе именно ближайшее сообщество через механизмы социального контроля и социальных ожиданий регулирует поведение мужчин и женщин в области вступления в брак, рождения и воспитания детей. Пока смертность была высокой (т. е. на протяжении почти всей истории человечества), социальные нормы успешно развивающихся обществ везде были направлены на поддержание высокой рождаемости, чтобы обеспечить хотя бы небольшое ее превышение над смертностью (значительным оно практически никогда не бывало). Не было слишком больших проблем и с тем, чтобы сдержать рождаемость в тех случаях, когда это было нужно - существовали механизмы социальной саморегуляции, например, повышение возраста вступления в брак или распространение безбрачия.

Возникновение политики населения в ее современной форме некоторые демографы связывают с экономической теорией общественных благ (Demeny 2003). Республиканские государства Нового времени стали восприниматься как ответственные за благоденствие жителей, в конце концов, свободные жители сами избирали представителей именно для того, чтобы те защищали их интересы, прежде всего производили общественные блага, которые люди не могли произвести для себя сами. Рождаемость в стране могла восприниматься как одно из таких общественных благ, а ее уровень мог трактоваться как слишком низкий или слишком высокий, с точки зрения «общего интереса» в представлении политиков, которым та или иная численность населения представлялась оптимальной.

Но появление на свет новых людей всегда, в конечном итоге, являлось результатом решений индивидов: помимо воздействия со стороны ближайшего окружения, важны эмоциональные причины и не всегда до конца осознаваемый расчет потерь и выгод от рождения каждого ребенка. Но и потери, и выгоды воздействуют не только на самих потенциальных родителей, но и на других людей в обществе. Например, в настоящее время очень популярна метафора детей в самолете, создающих дискомфорт и мешающих пассажирам, путешествующим без детей. Последние, в том числе и действительно бездетные, не считают себя обязанными входить в положение родителей, которым в этот момент еще тяжелее, и среди других аргументов приводят еще и тот, что они уже 
“скинулись” на помощь родителям, заплатив налоги. То есть в области рождаемости существует легитимный общий интерес для всех тех, кого это может затронуть. В то же время на индивидуальном уровне человек может очень ограниченно влиять на рождения у других людей. Появляется потребность в государственном регулировании в этой области, так же, как и в некоторых других: в воздействии на рождаемость для достижения агрегированных общих целей, влиянии на индивидуальные решения в направлении общего блага.

Самая ранняя формулировка вопроса роста населения как проблемы координации индивидуальных предпочтений и затем государственного вмешательства в область рождаемости в направлении агрегированного общего интереса была дана Уильямом Фостером Ллойдом, оксфордским математиком и экономистом, в 1833 г. (Lloyd 1968 [1833]). Для него был характерен мальтузианский подход, т. е. опасения, связанные с перенаселением, даже в случае, если все пары будут иметь только то число детей, которое они хотят. Ведь при падении смертности это желаемое количество детей может оказаться слишком большим для имеющихся ресурсов. Мальтус и его последователи рекомендовали не поддерживать рождения у бедняков экономически, чтобы избежать опасности перенаселения. С его точки зрения, общество не должно делить с родителями расходы на детей. Это можно считать политикой по сдерживанию рождаемости: создаются такие условия, при которых рациональное планирование будущего рождения детей или их отсутствия вознаграждается. В то время, в XVIII - начале XIX века, увеличивающийся спрос на оплачиваемый труд, включая детский, поддерживал рождаемость на высоком уровне, даже стимулировал ее. Однако росли и стандарты уровня жизни, возможности социальной мобильности в связи с урбанизацией. Это усиливало противоположную тенденцию - меньшее число детей означало больше шансов на лучшую жизнь для себя или имеющихся детей. Государственные программы поддерживали именно этот последний тренд, не очень вмешиваясь в функционирование экономики и ограниченно поддерживая бедных. Наиболее важными оказались запрет детского труда до определенного возраста и введение обязательного школьного образования. В результате увеличивались расходы на детей и уменьшались относительно быстро получаемые выгоды от них. При этом распространение информации о контрацепции и аборты оставались незаконными, что создавало барьеры на пути внутрисемейного сокращения рождаемости. Тем не менее рождаемость в индустриальных странах быстро сокращалась.

Потери в Первой мировой войне и последующих эпидемиях, а в начале 1930-х Великая экономическая депрессия показали, что нет гарантии того, что индивидуальные решения обязательно обеспечат равновесие между рождаемостью и смертностью на уровне, не приводящем к сокращению населения. Возникла потребность в корректирующем вмешательстве государства с теперь уже противоположной целью: увеличения рождаемости до уровня хотя бы простого воспроизводства. В некоторых странах были усилены санкции за аборты и контрацепцию, развернулись кампании государственной пропаганды рождаемости. Эффект оказался незначительным. Многообещающим представлялось экономическое стимулирование, перераспределение дохода в пользу родителей малолетних детей: вознаграждение (на тот момент) социально желаемого 
репродуктивного поведения и наказание за нежелательное 2 . В некоторых странах показатели рождаемости выросли незначительно и на короткий период, но не доказано, что все это как-то повлияло на реальный рост числа рождений в когортах. Количественные цели, заданные именно демографическими политиками той эпохи, не были достигнуты.

После Второй мировой войны внимание оказалось привлечено к быстрому росту населения в развивающихся странах, где к этому времени уменьшилась смертность и возникла общественная потребность в контроле рождаемости; высокая рождаемость препятствовала экономическому развитию и представлялась угрозой для мировой стабильности в будущем. Возникли организации, занимающиеся политикой контроля рождаемости на международном уровне. Ряд исследователей высказывали мнение, что доступность контрацепции и других средств контроля рождений важна, но потребность родителей в детях является основополагающей и на уровне политики работать надо с ней: усиливать рыночные «сигналы» о высокой стоимости детей из-за потерь в заработке родителей при заботе о малолетних детях, уменьшения или отсутствия вклада от детей в семейный доход и уменьшения вклада детей в обеспечение родителей в старости по сравнению с пенсией и накоплениями. Законодательно родительская ответственность за детей стала увеличиваться до всё более старших возрастов, экономически вклады в образование становились более интенсивными и растянутыми по времени, росли возможности трудоустройства женщин, а это было несовместимо с частыми и многочисленными рождениями, распространилось обязательное школьное образование, препятствуя оплачиваемой работе детей или их труду на семейной ферме, детский труд даже в домашнем хозяйстве становился незаконным или проблематичным, развивались системы пенсий и сбережений.

Но все эти факторы приводят к добровольному снижению рождаемости только в условиях, когда есть экономическое развитие. Государства же часто пытались подменить собой рынок, пытаясь заместить рост экономического благосостояния введением программ, стимулирующих желаемое поведение. В частности, развивались программы, занимающиеся распространением современной надежной контрацепции среди групп людей, пока еще не испытывающих артикулированной потребности в уменьшении числа рождений. Как и с программами по увеличению рождаемости 1930-х годов, сложно сказать, обусловлено ли падение рождаемости в большинстве развивающихся стран с тех пор в основном воздействием программ по распространению контрацепции и что произошло бы в их отсутствии. В некоторых странах (особенно яркий пример Китай) программы по снижению рождаемости имели однозначно принудительный характер. В других странах, например в Бразилии, снижение рождаемости произошло в отсутствие соответствующих программ. В Китае после недавней отмены политики «одна семья - один ребенок» пока не фиксируется существенного увеличения рождаемости. Некоторые исследователи считают, что и без воздействия специальных программ рождаемость в большинстве стран постепенно уменьшилась бы примерно до тех же показателей и за то же время, и лучшими

\footnotetext{
2 Подробнее о принятых в 1930-е годы программах этого рода в Европе и СССР см. (Захаров 2017: 195-214).
} 
средствами для этого были признаны экономическое развитие и рост женского образования.

Сейчас программы по распространению средств контрацепции и знаний о ней формулируют свои цели как удовлетворение потребностей людей в области охраны здоровья и помощь в осуществлении фундаментальных прав человека. На конференции в Каире в 1994 г. была подчеркнута роль образования женщин и возможностей для них участия в рынке труда и политического участия. Связь этих направлений с сокращением рождаемости не была отчетливо сформулирована, но большинство исследователей давно пришли к выводу, что рост уровня образования женщин создает у них потребность в рождении меньшего числа детей. Произошел поворот к политике по сокращению рождаемости в развивающихся странах к воздействию со стороны потребности, а не средств, в отличие от подхода, доминировавшего в течение нескольких десятилетий до этого.

Тем временем в развитых странах к концу XX века внимание политиков стал привлекать феномен рождаемости, снижающейся до уровня ниже простого воспроизводства населения в растущем числе регионов и стран. То есть сумма индивидуальных решений устойчиво стала создавать дефицит, а не избыток населения. Но на этот раз в большинстве стран ситуация не вызвала алармистской реакции и/или принятия политик, эксплицитно нацеленных на повышение рождаемости. На наш взгляд, это связано с таким развитием общественных представлений, когда открытый пронатализм в любой ситуации не воспринимается большинством населения стран как соответствующий их общему интересу. Сложное отношение к «манипулированию» человеческим поведением может быть обусловлено также исторически скомпрометированными социальноинженерными и евгеническими концепциями, когда-то влиявшими на политику в области рождаемости (см. следующий раздел). С каждым годом становится всё более популярным представление о том, что попытки «заставить» людей вести себя определенным образом являются крайне неэтичными и нарушающими права человека.

\section{3. СОЦИАЛЬНАЯ ИНЖЕНЕРИЯ И ЕВГЕНИКА: (НЕ)ЗАБЫТЫЕ ОСНОВАНИЯ ПОЛИТИЧЕСКОГО ВОЗДЕЙСТВИЯ НА ПОВЕДЕНИЕ}

Карл Поппер определяет социальную инженерию как совокупность подходов прикладной социологии, направленных на рациональное изменение социальных систем на основе фундаментальных знаний об обществе и предсказании возможных результатов преобразований (Поппер 1992). К социальной инженерии имеют также отношение психология, политология и другие социальные науки. Задачей, которую ставит перед собой социальная инженерия, является направление, упорядочивание и оптимизация процесса создания, изменения и воспроизведения новых социальных реальностей. В некотором смысле, например, само «построение нового общества» и попытка «создания нового человека» в СССР при помощи совокупности воспитательных и репрессивных мер можно отнести к социальной инженерии в ее широком понимании как социального эксперимента. В более узком и позитивном смысле часто социальная инженерия связана с формированием оптимального взаимодействия людей в процессе производственной деятельности, в 
частности, в СССР еще в 1920-е годы она получила развитие в области научной организации труда (Гастев 1972), затем в 1980-е в рамках индустриальной социологии. В дальнейшем она применялась в области попыток формирования общественного мнения и в целом в политтехнологиях.

Демографическая политика в области рождаемости также связана со стремлением изменить некоторую область социальной реальности, а именно репродуктивное поведение людей. С некоторой точки зрения, таким образом, можно назвать ее социальной инженерией, направленной на изменение взаимоотношений семьи и государства. Можно даже считать длительную историю демографической политики неким экспериментом в естественной среде, направленным на выявление возможности эффективности социальноинженерных методов как таковых в ситуации, когда люди в целом все менее настроены на желаемое действие - увеличение числа рождений. Пока получается, что эффективности практически нет. Это можно объяснить тем, что, согласно критике Ф.А. фон Хайека (1990), сторонники социальной инженерии иллюзорно полагают, что человек может по собственному желанию выбирать, куда ему идти дальше; он считал ошибкой их стремление не допустить любыми способами хаотическое развитие социальных институтов. На самом же деле социальные институты не могут быть полностью сконструированы государством, как и не могут быть полностью под его контролем, они самостоятельно возникают и эволюционируют, это саморазвивающиеся структуры. По мнению Ч.Р. Миллса (Mills 1951), социальная инженерия - это научное оправдание манипуляций человеческим поведением.

На мировоззренческие основания демографической политики в первой половине $\mathrm{XX}$ века повлияла также евгеника. Основателем евгеники как научной дисциплины является Фрэнсис Гальтон. Он предложил применить к воспроизводству человеческого рода методы селекции, применявшиеся в сельском хозяйстве, чтобы способствовать размножению «приспособленных» (позитивная евгеника) и препятствовать продолжению рода «неприспособленных» (негативная евгеника), чтобы препятствовать «вырождению» человечества (суммирование идей см. в (Galton 1904)). В конце XIX века его идеи были подхвачены многими в русле нараставшего национализма и капитализма в разных европейских государствах, в связи с чем «неприспособленными» достаточно часто стали объявлять представителей определенных рас и классов (Кременцов 2014). В дальнейшем евгеника была скомпрометирована политикой гитлеровской Германии, печально известной не только уничтожением евреев, но и принудительной стерилизацией «умственно неполноценных», а также «разведением» истинно арийских детей, которых затем выращивали в специальных детских домах. Но до Второй мировой войны эти представления успели повлиять на формирование концептуальных направлений развития демографической политики в большом числе развитых стран, в том числе в СССР. В некоторых штатах США еще в первое десятилетие XX века были приняты законы о принудительной стерилизации преступников и других «неполноценных». Распространились такие стерилизации (к которым вынуждали все же в основном экономическим давлением, но были приняты и соответствующие законы) и в Скандинавских странах, Швейцарии и некоторых других. В СССР существовало Евгеническое общество с 1920 по 1930 г., и оно было настолько влиятельно, что авторитет его руководителей оказал воздействие на содержание Семейного Кодекса 1926 г. 
(включение в него норм о запрете браков между близкими родственниками, людьми моложе 18 лет, о необходимости проверки здоровья молодоженов перед вступлением в брак) (Кременцов 2014). Евгенические идеи «улучшения человечества» были близки взглядам большевиков тех времен, не удивительно, что наркомы просвещения и здравоохранения Луначарский и Семашко поддерживали евгенику (Кременцов 2014).

В 1920-1930-е годы в СССР и других европейских странах организовывались конкурсы здорового ребенка, победа в которых обеспечивалась во многом благодаря здоровью родителей, была обусловлена наследственностью. И даже когда Евгеническое общество было разгромлено, в 1936 г. при принятии закона о запрете абортов список медицинских оснований для прерывания беременности, обсуждавшийся в медицинском сообществе целый год, включал такие заболевания, как, например, шизофрения (по представлениям тех времен - наследственная болезнь), т. е. оставалось стремление препятствовать рождению людей с возможными проблемами, а не только прерывать беременность в случае угрозы жизни матери (Кременцов 2014). В некоторых странах в 1930-е годы «позитивная» демографическая политика — выплаты и льготы семьям - была эксплицитно направлена только на представителей основной национальности. Интенсивная медикализация, произошедшая в период между войнами во многих странах, в том числе и в СССР, также была связана с евгеническими идеями, она стала одним из инструментов «социального контроля» в процессах государственного строительства и модернизации (Stepan 1996). В Скандинавии, Швейцарии, США программы стерилизации часто касались одиноких матерей, поскольку считалось, что сам факт внебрачной беременности косвенно свидетельствует о слабоумии женщины (Bashford, Levine 2010; Broberg, Roll-Hansen 1996). Некоторые ученые связывают с евгеникой также и идеологию и практику контроля за ростом населения Земли, проводившуюся с 1950-х годов, так как она была направлена в основном на сдерживание рождаемости в развивающихся странах, в то время как в развитых одновременно существовали программы по поощрению рождаемости - тем самым подчеркивалась разная ценность детей разных расовых и классовых групп (Kühl 2013). Таким образом, пути воздействия евгенических представлений на политику народонаселения были многочисленными и разнообразными (Кременцов 2014).

В последние десятилетия в связи с развитием репродуктивных технологий почти забытая и осуждаемая евгеника расцвела вновь, так как появилась возможность очень точного определения наличия у плода реальных наследственных заболеваний и выбора родителями таких детей, которых они предпочитают родить и растить. Пока практики выбора/модификации определенных генетических свойств, за исключением случаев подтвержденных наследственных заболеваний, почти везде запрещены, то есть и тут появилась область демографической политики в виде запретительного законодательства (Исупова 2017; Иванюшкин, Лапин, Смирнов 2013).

Как бы то ни было, политики, имеющие потенциал влияния на увеличение рождаемости, существуют и развиваются, но их декларируемые цели практически никогда не бывают откровенно демографическими - обычно, речь идет о качестве жизни семей с детьми, улучшение которого может косвенно повлиять на увеличение числа рождений. 


\section{4. СЕМЕЙНАЯ ПОЛИТИКА: КОНЦЕПТУАЛЬНЫЕ ДЕБАТЫ}

Рассмотрим теперь концептуальные разногласия уже внутри поля семейной политики как таковой. Исторически она «выросла» из социальной политики, являясь ее относительно поздно сформировавшимся разделом. Она представляет собой публичное государственное вмешательство в семейные вопросы с помощью различных законодательных инициатив, касающихся брака, родительско-детских отношений, наследования, обязательств по школьному образованию, возраста, когда разрешено начинать и заканчивать работать, жилищной политики и др. Не только содержание программ, но и декларируемые цели и здесь менялись с течением времени; всегда существовали и межстрановые различия. В литературе (Kamerman, Kahn 1978; Kamerman 2010) отмечается различие между эксплицитной и имплицитной семейной политикой: первая специально предназначена для достижения определенных целей в отношении демографического поведения людей внутри семьи или поведения семьи в целом, а вторая имеет основными целями что-то, не относящееся к рождению детей в семьях, но способное косвенно на него повлиять. Есть страны, где существует эксплицитная семейная политика например, Франция), есть такие, где она скорее имплицитна (США). Во Франции семейная политика имеет уже более чем вековую историю, в Италии, Германии и некоторых других европейских странах она сформировалась в период сразу после Первой мировой войны. Переход страны из группы с имплицитной политикой в группу с эксплицитной может происходить без всякого изменения содержания политик просто за счет переопределения, «переназвания» целей и задач. Например, отпуск в связи с рождением ребенка и родительский отпуск по уходу за детьми переопределяются не как меры политики в области регулирования рынка труда, а как меры семейной политики (или происходит обратное «переименование»).

В настоящее время в связи с растущим многообразием форм семьи существует концептуальная дискуссия относительно того, что является объектом воздействия семейной политики: семья или семьи.

Кто приоритетен для политиков: семья как единое целое или отдельные индивиды как члены семьи, а семья как целое, - только косвенно? Создание и государственное финансирование детских садов адресовано мамам, детям или семье в целом? Государство поддерживает только один тип семьи (состоящую в законном браке пару с детьми), а остальные исключаются, или все типы семей (одинокие родители, гомосексуальные пары, сожительствующие партнеры, семьи без детей)? Многие авторы склоняются к мысли, что важны только семьи с детьми (что показывает крепкую телеологическую связь современной семейной политики с прежней демографической), другие делают акцент на гендерном аспекте семейной политики, на ее роли в изменениях жизни женщин и мужчин, их гендерных ролей. Есть мнение, что политики в отношении людей разного возраста, например стариков, также должны быть переопределены как семейные, ведь они касаются межпоколенческих обязательств в семьях и отчасти их формируют (например, (Saraceno, Keck 2010)). Всё это ценностные вопросы.

Финансовые обязательства и обязанности, связанные с заботой (по отношению ко всем зависимым и/или нуждающимся в физической помощи членам семьи), собственно, лежат в основе всех видов вмешательства государства в семейные дела. При анализе важно 
различать программы, сектор, в котором они действуют, цели и инструменты их достижения. Потребности маленького ребенка в заботе (сектор) могут удовлетворяться как с помощью развития услуг (детский сад), так и финансовой поддержкой матери (родителя), а всю заботу будет осуществлять она сама. Какой из этих инструментов будет выбран, определяется целями политики и лежащими в их основе ценностями относительно “правильного” поведения, которое надо поощрять.

В европейских странах в течение последних десятилетий эксплицитными целями политических программ являются содействие участию женщин в рынке труда, поддержка баланса между семейной жизнью и работой и инвестирование в формирование человеческого капитала детей. Понятно, что все эти цели способствуют развитию сети детских садов и как центров раннего образования детей, и как способа облегчить женщинам участие в рынке труда и сбалансировать трудовую нагрузку.

В широком смысле понятие «семейная политика» включает все сферы жизни, регламентирование которых государством может влиять на качество жизни семей: такие, как занятость, транспорт, продовольственное обеспечение, образование, медицина и др. В более узком смысле, которым, как правило, оперируют специалисты в области исследований семейной политики, понятие сводится к финансовой поддержке семей, услугам и пособиям для работающих родителей, политике в области образования и медицины и семейному законодательству. Даже и такое узкое определение охватывает огромное число разнообразных программ.

Сразу после Второй мировой войны были приняты некоторые программы, основанные на традиционных представлениях о семье, где кормильцем является мужчина и только в случае его нежелательного отсутствия эту роль берет на себя женщина. Этот подход был естественным продолжением подхода к семейной политике, господствовавшего и в прежние эпохи, изменения в представлениях, согласно которым помощь должна быть адресована непосредственно тому, кто осуществляет родительские задачи, при этом формы семьи могут быть самыми разными, происходили сложно и непросто в течение двух следующих десятилетий даже в самых динамично развивающихся и демократических обществах.

Начиная с 1970-х годов, политики стали постепенно признавать разнообразие ситуаций, в которых живут взрослые и растут дети. Прежде всего изменились гендерные роли, увеличилось число семей, где работают оба супруга, брак стал нестабильным, другими стали семейно-родственные взаимодействия, экономически уязвимые формы семей, в которых растут дети (раньше это чаще были многодетные семьи или семьи вдов, теперь это огромное количество семей одиноких женщин, растящих детей). Был

Проводилось много реформ, но единый теоретический подход так и не выработан. Далеко не во всех странах сформулированы цели и идеологии семейной политики в целом. Изменения экономической ситуации, череда экономических рецессий, увеличение структурной нестабильности, меняющаяся емкость/спрос на рынках труда стимулировали стремление государства к тому, чтобы как-то помочь семьям бороться с бедностью, в том числе и по демографическим соображениям. Экономическое положение семей сказывается и на желании рожать детей — ведь все большему числу потенциальных родителей 
становится понятно, что ребенок - это не только немедленные расходы на младенца, которые можно как сократить почти до нуля, если кормление происходит исключительно грудным молоком, а все детские вещи взять у кого-то бесплатно, так и увеличивать почти до бесконечности, общество потребления позволяет покупать все больше и больше все более дорогих детских товаров - но и содержание растущего, а то и взрослого, человека до всё более позднего возраста.

В то же время встал вопрос об ограничении быстрого нарастания финансовых обязательств государства (многие государства продолжают хотеть, чтобы население воспроизводилось, но не готовы полностью взять на содержание всех детей до окончания ими образования). В результате, в растущем числе случаев была усилена адресность семейной политики, меры стали зависеть от дохода семьи. Директивы Евросоюза сыграли некоторую унифицирующую роль в области семейной политики входящих в него стран, мотивировав те из них, где до этого не было соответствующих программ, к их введению (так получилось, например, с родительским отпуском).

Программы семейной политики в странах Европы и за ее пределами делятся на финансовые и предоставляющие время/услуги. Дети и другие зависимые члены семьи потребляют как деньги, так и время своих родителей. Поэтому важны как различные пособия и налоговые вычеты (деньги), так и время (родительские отпуска) и экономящие его услуги (ясли и детсады). Идеологии фамилиализма соответствует ситуация, когда отпуск по уходу за ребенком короткий, а детских садов/яслей мало, или когда отпуск длинный, но после его окончания детские сады недоступны, а большая часть заботы о детях ложится на членов семьи, обычно на женщину. Эта идеология подразумевает, скорее, финансовую помощь со стороны государства. Напротив, дефамилиализм - идеология, подразумевающая внесемейную помощь именно в фактическом осуществлении заботы о членах семьи (услугах). Первая ситуация характерна для Италии, вторая - для ряда стран Восточной Европы. Короткий или длинный отпуск при доступных яслях и детсадах с раннего возраста - это дефамилиализация (пример первого - Нидерланды, второго Франция).

Влиятельная типология концепций и подходов к семейной политике предложена Эспин-Андерсеном в 1994 г., впоследствии она несколько модифицировалась, но продолжает использоваться. В соответствии с этой типологией, скандинавский социальнодемократический режим основан на идеях универсальной поддержки государством всех типов семей с детьми, гендерного равенства, на модели семьи, в которой оба родителя работают («общество работающих взрослых»). Консервативный (корпоративный) режим (Франция, Германия, Нидерланды) поддерживает разные семьи по-разному в зависимости от статуса занятости родителей, для него характерно более традиционное представление о гендерном разделении труда. Южноевропейский режим характеризуется фрагментированностью программ, связанных с характером занятости членов семьи и стремлением использовать как универсальные, так и частные сервисы и пособия. В этих странах поддержка минимального дохода семей на национальном уровне не гарантируется. Либеральный режим, характерный для англо-саксонских стран, связан с более высоким уровнем поддержки бедных, чем в Южной Европе, но при этом люди с достаточными доходами, как предполагается, должны решать связанные с выращиванием детей вопросы 
самостоятельно, используя рыночные средства (хотя и тут происходят некоторые изменения с течением времени, см. ниже о случае США).

Режимы семейной политики сформированы на основе давних социокультурных традиций разных стран. Среди прочего существенное влияние на них оказали дебаты между неомальтузианством и пронатализмом национальных государств рубежа XIX и XX веков. Именно тогда пронатализм оказался четко связанным в сознании политиков с традиционной семьей и необходимостью поддерживать именно эту форму устройства семейно-родительских отношений. Поэтому до самого последнего времени у многих из них существовало недоверие к другим формам, которые воспринимались как проявление «кризиса семьи», рождение и «достойное» воспитание детей с ними не ассоциировалось. В результате и отношение к детским садам и яслям, к пособиям на детей тем, кто их растит (вместо пособий отцам) было двойственным и непоследовательным. Многим политикам казалось, что такие меры разрушают традиционные семейные и гендерные устои, брак как таковой, материнство и родительство. Отголоски этих проблем можно увидеть в характерных особенностях режимов семейно-демографической политики в разных странах в настоящее время.

Ряд исследований (Gauthier 2002) показывают, что, хотя типология ЭспинАндерсена продолжает оставаться удобным методологическим инструментом для анализа систем семейной политики в разных странах, с течением времени ситуация несколько меняется, происходят подвижки как в “наполнении” кластеров странами, так и в системах политики отдельных стран, которые не всегда уже можно однозначно отнести к сформированным изначально типам. Например, в 1972 г., почти за два десятилетия до появления модели Г. Эспин-Андерсена, еще невозможно было однозначно выделить три или четыре кластера, дисперсия между отдельными странами по расходам на семейную политику и поддержке работающих родителей была слишком велика. Особенно велики были различия между странами консервативного режима. А южно-европейский кластер вообще невозможно было выделить. В 1985 г. кластеры видны достаточно четко, но Греция, скорее, подходит под признаки корпоративного режима, чем южно-европейского. К 1999 г. различия между либеральным и социал-демократическим режимами усилились, а дисперсия внутри социал-демократического и консервативного кластеров увеличилась. Южно-европейский кластер, где за это время увеличились расходы на семейную политику, заметно приблизился к либеральному и к некоторым странам из консервативного кластера (Франции, Нидерландам, Ирландии).

В дальнейшем, с расширением Евросоюза и включением в исследования новых стран, типология их семейных политик еще более модифицировалась и усложнилась (см. описание системы Эйрнса и Бойе для 2009 г. в (Захаров 2016)). При составлении своей типологии Эйрнс и Бойе принимали во внимание структуру семьи и гендерные отношения разных стран, фамилиализацию/дефамилиализацию (т. е. характерный для страны режим предоставления заботы) и права социального гражданства стран (т. е. право получать заботу и право ее предоставлять). При этом индикаторами служили продолжительность и величина оплаты отпуска по уходу за ребенком, возможность гибкого графика работы, наличие развитой и доступной системы детских садов и яслей. В 2009 г. к модели семейной заботы, по-прежнему характерной для Южной Европы, присоединились две балтийские 
страны. Финляндия попала в кластер стран с длинным отпуском по уходу за ребенком, выделяясь в нем наличием системы детских садов и высокими выплатами. Франция и Бельгия были объединены в одном кластере с Данией и Швецией в связи с наиболее высокими выплатами и их разнообразием, а также благодаря наличию развитой системы детских садов. Корпоративный режим остался представленным Германией, Австрией и Люксембургом, отличаясь от либерального (Великобритания и Нидерланды) более длительным отпуском по уходу за ребенком. Но оба эти режима поддерживали гибкий график и неполный рабочий день для родителей, прежде всего, для матерей.

Существуют и другие типологии европейских семейных политик. Анттонен и Сипила (Anttonen, Sipilä 1996) выделили кластеры по степени, в которой государственные усилия направлены на благосостояние детей и стариков, т. е. насколько велика степень дефамилиализации в этих двух областях соответственно. В первый кластер попали страны, где государство было щедрым к старикам, но не к детям (Нидерланды, Норвегия и Великобритания), во второй - к детям, но не к старикам (Франция, Бельгия и Италия); в третий - ко всем одинаково (Дания, Финляндия и Швеция), в четвертый - ни к кому (Португалия, Греция, Испания и Ирландия). Позже эти же авторы с еще одним соавтором (Anttonen, Baldock, Sipilä 2003) отказались от своей типологии, поскольку пришли к выводу, что политики каждой страны представляют собой сложное и подчас противоречивое целое. Кауфман (Kaufmann 2002) создал аналогичную типологию, основанную просто на степени щедрости поддержки. Беттио и Плантенга (Bettio, Plantenga 2004) также создали типологию режимов заботы, которая включает рыночные способы ее осуществления, в частности, использование труда мигрантов. Есть ряд типологий, связанных с гендерным измерением (Orloff 1993; Lewis 1992; Korpi 2000), они основаны на различиях в степени поддержки доступности рынка труда и баланса между семьей и работой для женщин и усиления или ослабления модели семьи с мужчиной-кормильцем, а также в соотношении между услугами и денежными пособиями. Типология Bahle (2008), охватывающая 25 стран Евросоюза, основана на различиях в степени государственной поддержки баланса между семьей и работой (пособия по материнству/родительству и услуги по уходу за детьми) и семейного дохода (в форме семейных и детских выплат). У него получилось пять кластеров от наиболее до наименее универсальных и щедрых государств. Эти различия он связывает с исторически сложившимися отношениями между государством и церковью. В основе типологии Брэдшоу (Bradshaw 2006) (15 европейских стран) лежит благосостояние детей в разных семейных ситуациях, она основана на анализе пособий и выплат. Типология Дэли (Daly 2011) основана на силе имплицитных мотиваций и разнообразии национальных философских ориентаций, создающих различные системы отношений рынок-государствосемья. Она выделяет: 1) страны с пронаталистской и просемейной ориентацией (Франция и Бельгия), для которых рождаемость, семья и национальный интерес слиты воедино; 2) страны, где предполагается, что в семью как целое лучше вмешиваться минимально, поддерживая только уровень дохода при необходимости (Германия); 3) страны, для которых важно равенство между мужчиной и женщиной, но также и между детьми из разных семейных ситуаций, и индивидуальная автономия важнее семьи как целого (Скандинавские); 4) страны, где главной является не поддержка семьи как таковой, а стремление не допустить, чтобы хоть кто-то жил в нищете (США, Великобритания, Австралия). Лейтнер (Leitner 2003) и Сарацено и Кек (Saraceno, Keck 2010) предложили как 
критерий различения именно фамилиализацию/дефамилиализацию и выделили три группы: фамилиализм де-факто, «по умолчанию», когда уровни любой поддержки очень малы; поддержанный фамилиализм, когда семьям полагается довольно много выплат, включая налоговые вычеты и оплачиваемые отпуска, лишь бы вся ответственность за заботу и основная (за финансовое содержание семьи) оставалась на ее членах; и дефамилиализм, когда ответственность за заботу в большой степени ложится на общество. Первые два варианта усиливают традиционные гендерные роли, а последний помогает уменьшить степень традиционности. Антрэ (Hantrais 2007) выделяет традиционный фамилиализм, типичный для Южной Европы, и рефамилиализм, существующий в постсоциалистических странах.

В целом можно сказать, что историко-культурные традиции оказывают влияние на формирование режима семейной политики в стране, но, видимо, не во всех случаях являются единственным или даже доминирующим фактором. Кластеры меняются с течением времени, и страны с совершенно разной историей могут попадать в очень похожие семейно-политические ситуации (например, южноевропейские и балтийские в 2009 г.), яркие представители разных кластеров могут сближаться по характеру показателей (Франция и Швеция), православные традиции не препятствуют Греции оказаться в консервативном кластере, а различия между либеральным и южно-европейским режимами иногда очень малы. Однако различия в величине «ответа» со стороны государств на вызовы низкой рождаемости продолжают сохраняться с течением времени. В то же время быстрое падение рождаемости в Европе с 1960-х годов не привело к резкому увеличению выплат семьям (но они и не уменьшились существенно) в связи со старением населения и перераспределением социальных фондов в пользу пенсий. Поддержка работающих матерей с тех пор везде увеличилась, хотя в либеральном кластере несколько меньше, чем в остальных.

Теории, определяющие подходы к тому, почему семейная политика вообще оказалась необходима, можно сгруппировать как такие, которые связывают происходящее с объективным процессом индустриализации, и те, для которых в центре происходящих изменений находится деятельность социальных акторов, различных институтов и организаций (Gauthier 2002). Индустриализация изменила структуру общества, что создало на ранних стадиях новые социальные проблемы: крайнюю бедность работающего населения, широкое использование детского труда. Вмешательство государства потребовалось, чтобы изменить эти практики путем введения законодательства о детском труде и обязательного школьного образования. Пришлось задуматься и о финансовых мерах поддержки семей. В недавнее время переход к постиндустриальным обществам привел к несовместимости семейных и рабочих обязанностей во многих случаях, прекарности занятости и, соответственно, невозможности пользоваться различными социальными гарантиями на рабочем месте, возникновению новой бедности. В это же время более нестабильным стал и брак, а в тех случаях, когда брачное законодательство оказалось «перегруженным» различными гарантиями партнерам, стало распространяться внебрачное сожительство, требующее меньше ответственности от партнеров на законодательном уровне. Все это привлекло внимание государственных политиков и 
потребовало вмешательства в ситуацию, чтобы как-то по-новому поддержать взрослых, растящих детей.

Но такие теории подразумевают, что общие вызовы в экономической и социальной ситуации, по идее, должны привести и к общим, одинаковым в разных странах семейнополитическим решениям, а этого не происходит.

Вторая группа теорий фокусируется на индивидуальном факторе, роли отдельных институтов в развитии семейной политики, таких как политические партии, активистские некоммерческие организации, национальные правительства и др. Имеет значение «сила» всех этих акторов: влиятельность левых партий и организаций, степень централизованности национальных правительств и др. Эти теории в большей степени принимают во внимание культурно-исторический контекст стран. Например, именно они позволили объяснить особенности развития политики в США (Ooms 2019).

Второй подход несколько лучше поддерживается результатами исследований. Было показано, что превалирование денежных выплат скорее связано с католическими традициями и с представленностью католических партий в парламенте. Кроме того, с денежными выплатами положительно связаны длина периодов, в течение которых страной управляют левые партии, процент голосования за левых, наличие корпоративной культуры и централизация управления (Gauthier 2002). В целом на величину всех трат на семейную политику положительно и заметно влияет правление христианскодемократических партий и также положительно, но менее заметно - социалдемократических (там же).

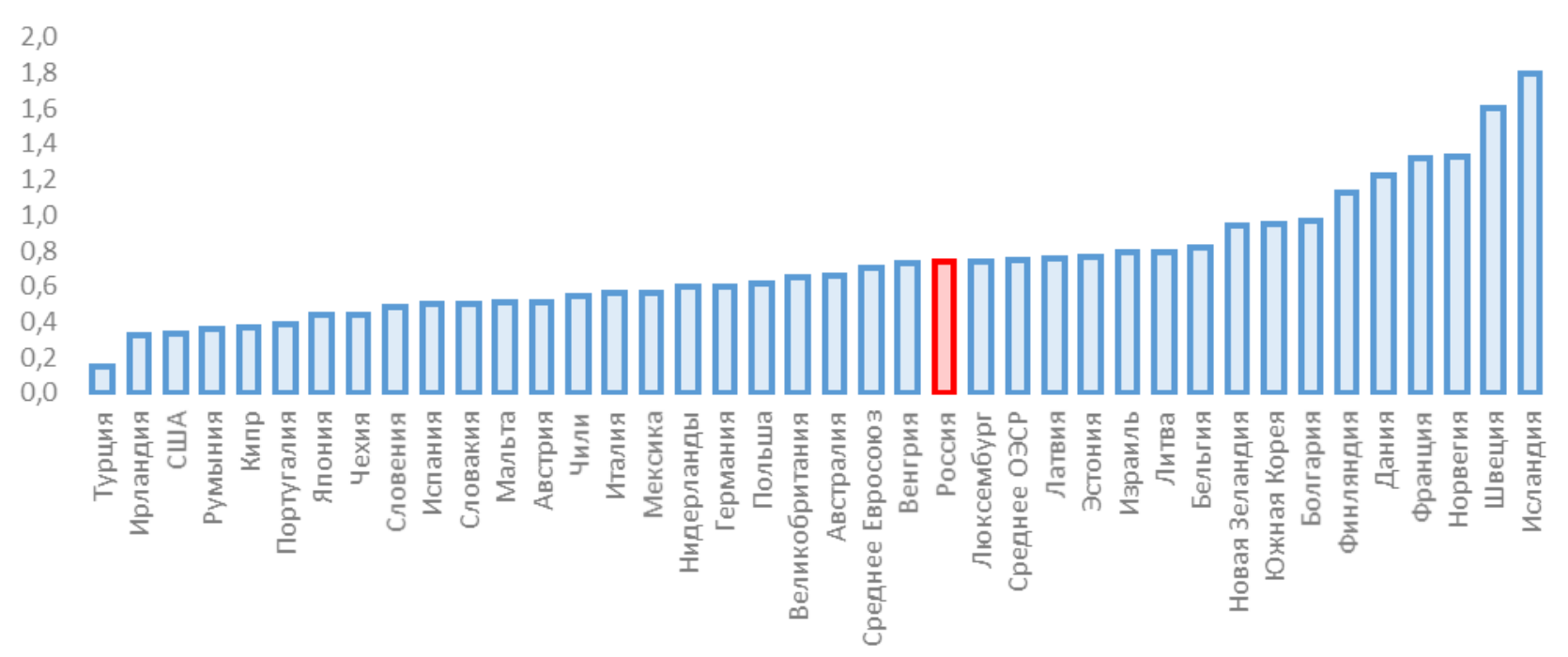

Источник: Расчеты автора по даннылм ОЭСР и Росстата.

Рисунок 1. Государственные расходы на дошкольные учреждения, \% ВВП, 2015 или самые поздние доступные данные

При попытках оценить и исследовать государственную поддержку семей количественно также используются два базовых подхода (Gauthier 2002). Первый предполагает построение индикаторов, отражающих величину поддержки, получаемой разными типами семей (Bradshaw 2006). Но такие данные доступны не по всем 
странам и не за все годы. Второй подход предполагает использование более агрегированных индикаторов, позволяющих оценить меру общей интенсивности вовлеченности государства в поддержку семей. Используется, например, индикатор государственных расходов на семейные выплаты в целом (Kamerman 2010). Из него можно вычленить поддержку содержания детей в детских садах, что мы и попытались сделать для данной работы, по последним имеющимся данным ОЭСР и по данным Росстата для России (рисунок 1). Нам представляется, что, при имеющихся тенденциях увеличения пропорции работающих женщин в развитых странах, именно эта политика могла бы быть приоритетной, так как учитывает предпочтения относительно образа жизни значительной части населения, а также мотивирует родителей работать и зарабатывать; при этом расчет на исключительно рыночные механизмы работы яслей и детских садов приводит к их чрезмерной дороговизне и не оправдывает себя, вынуждая женщин выбирать между работой и материнством и негативно влияя на рождаемость. Можно видеть, что эти расходы в процентах ВВП везде очень невелики, не превышают $1 \%$.

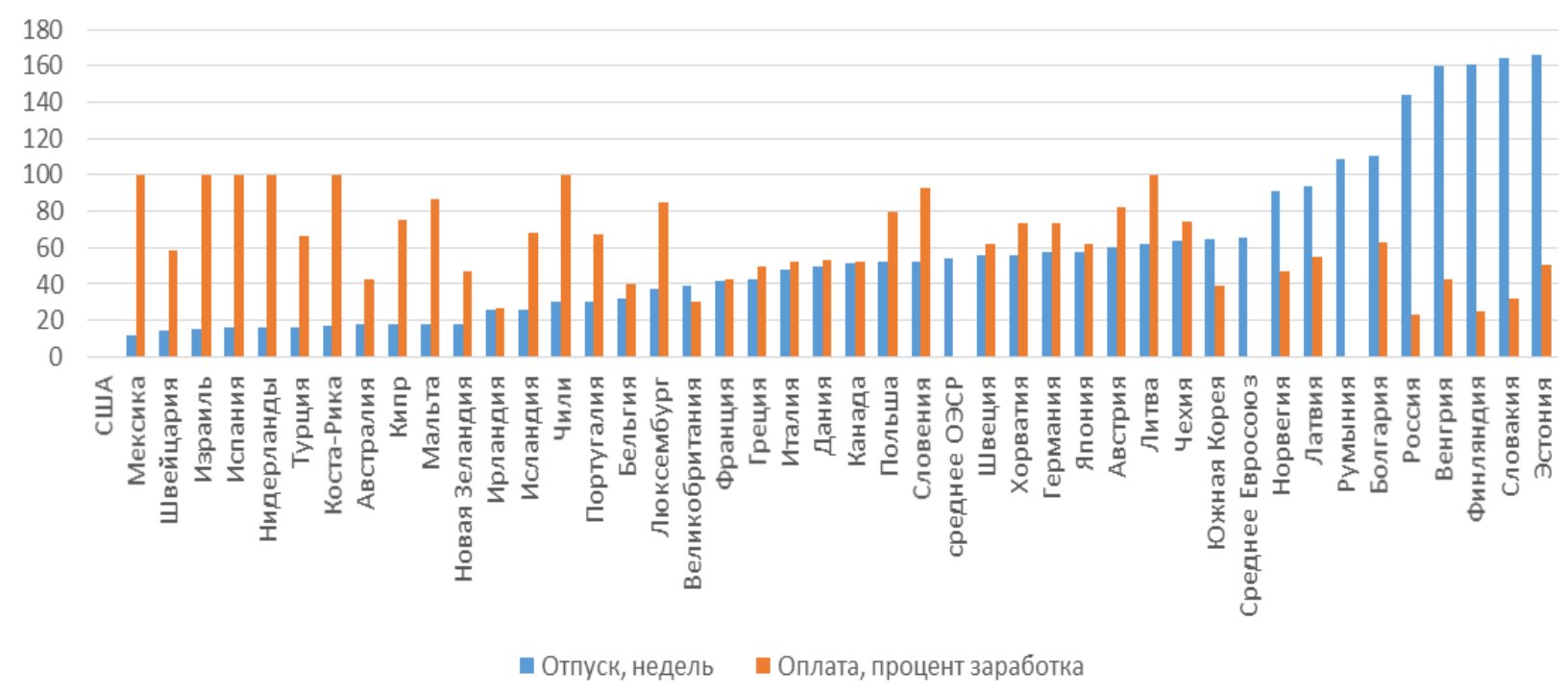

Источник: Данные ОЭСР и Росстата.

\section{Рисунок 2. Материнский отпуск в связи с родами и по уходу за ребенком - продолжительность и оплата, 2018}

Часто используются также важные показатели продолжительности отпуска по уходу за ребенком и его оплаты (рисунок 2). На рисунке 2 в целях удобства анализа объединены отпуска по материнству и по уходу, доступные женщинам. Можно видеть, что прослеживается тенденция более полной оплаты отпуска при его меньшей длине, что может отражать разные концепции взаимодействия семейной политики и материнского поведения женщин: «общества работающих взрослых», где предполагается, что в связи с материнством женщина лишь на короткое время уходит с рынка труда, но уровень ее жизни при этом не должен падать, и создается мотивация к ее как можно более быстрому возвращению в трудовой строй; более консервативная концепция, согласно которой материнство предполагает долгий период вне работы, у женщины есть своя специфическая роль, связанная с семьей, и поддерживать ее финансово тоже должна, скорее, семья, 
государство же - лишь частично, оно вынужденно выплачивает небольшие деньги, поскольку семья не всегда хорошо с этим справляется.

\section{5. ИСТОРИЯ КОНЦЕПЦИЙ ПОЛИТИКИ В ОБЛАСТИ РОЖДАЕМОСТИ В СССР и России}

В работах советских демографов 60-х и начала 70-х годов говорилось, как правило, о «политике народонаселения»: «Теория и политика народонаселения» (Валентей 1967); «Вопросы теории и политики народонаселения» (Валентей, Бурнашев 1970). В то время под демографической политикой в нашей стране понимали, как правило, меры по ограничению рождаемости через планирование семьи и в основном в развивающихся странах (Валентей $1971)^{3}$. В монографии под редакцией Д.И. Валентея В.В. Бодрова писала как о политике народонаселения (под которой понимались различные меры, направленные на улучшение жизни людей), так и об «особой» демографической политике, понимая под ней целенаправленные мероприятия по изменению возрастной структуры и миграционного движения населения (Бодрова 1971).

Первым в России определил соотношение демографической политики и политики народонаселения Д.И. Валентей. С его точки зрения, соотношение между понятиями иерархическое: политика народонаселения является составной частью социальноэкономической политики, это «...система мероприятий, прямо или косвенно направленных на изменение условий жизни и труда населения, количественных и качественных характеристик населения» (Валентей 1971:12). Демографической политикой он считал «совокупность мероприятий, регулирующих демографические процессы», при этом имея в виду только воспроизводство населения (Валентей 1971:14). С его точки зрения, демографическая политика относилась к политике народонаселения как часть к целому (в свою очередь политика народонаселения является составной частью социальноэкономической политики), при этом первая включала в себя вопросы социальной мобильности, естественного движения населения, а также миграции и расселения (там же). Другие исследователи в это же время считали правильным употреблять термины «демографическая политика» и «политика народонаселения» как тождественные друг другу (Лармин 1975).

В.П. Пискунов и В.С. Стешенко (1974) понимали демографическую политику скорее как социальную инженерию, а именно как систему мероприятий, направленных на формирование желательного для общества осознанного демографического поведения его членов, считая демографические процессы косвенно управляемыми, развивая представления, характерные для многих ученых как СССР, так и Европы 1930-х годов, в те времена связанные с социально-инженерными и евгеническими представлениями (подробнее см. выше). СССР в 1970-е и 1980-е годы был страной с огромными региональными различиями в рождаемости, что мотивировало ученых размышлять о «демографическом оптимуме», т. е. о «среднедетности» (Антонов, Медков, Архангельский

\footnotetext{
${ }^{3}$ См. обзор подробнее в (Елизаров 2017).
} 
2002), «сравнительно низкой рождаемости» (Кваша 1981), и разрабатывать меры как по снижению, так и по повышению рождаемости, понимая, что это части одного целого демографической политики. В дальнейшем (Валентей, Араб-Оглы 1985) одним из компонентов политики народонаселения была названа, кроме условий труда и условий жизни, также политика в области образования, а в демографическую политику не была включена социальная мобильность.

А. Антонов считал, что задачей политики в области рождаемости должно стать усиление потребности семьи в детях, а не фактическая рождаемость, как таковая, т. е. рост репродуктивных намерений (Антонов, Сорокин 2000). В.М. Медков (2002) выделил такие принципы демографической политики, как:

1) суверенность семьи;

2) свобода выбора;

3) общественный договор;

4) единство целей федеральной и региональной политики;

5) социальное участие.

Подразумевается, что семья независима от государства, имеет право самостоятельно принимать любые решения о своей жизни в соответствии с собственными интересами и целями. Свобода выбора предполагает существование в обществе возможности выбирать любой тип семьи и семейного поведения. Принцип общественного договора связан с тем, что, выполняя общественно значимые функции, семья имеет право потребовать у общества и государства обеспечение всесторонней поддержки своей жизни. Цели политики не должны зависеть от особенностей демографической ситуации в разных регионах страны. Семья и общественные организации должны иметь право голоса при разработке мер политики. Все эти принципы вызывают критическое отношение у многих ученых. Для нас в этой статье особенно важно критическое отношение к первым двум принципам, так как сама идея демографической политики предполагает ограничение суверенности семьи и свободы выбора.

В истории России открыто цели непосредственно стимулирования рождаемости, с точки зрения С. Захарова (Захаров 2006), чуть ли не впервые были названы политиками как основные только в комплексе мер 2006 г. при В.В. Путине, до этого всегда назначение принимаемых мер обозначалось скорее как «помощь семьям». Это верно и в отношении мер 1930 -1940-х годов, и в 1980-е годы. Ранее пронатализм можно было «считать» лишь из самого списка мер и преамбул документов. Например, знаменитые законы сталинской эры, известные в широких кругах как постановления о «запрете абортов» и о «запрете развода», на самом деле имеют следующие названия:

- Постановление ЦИК №65 и СНК СССР №1134 от 27 июня 1936 г. «О запрещении абортов, увеличении материальной помощи роженицам, установлении государственной помощи многосемейным, расширении сети родильных домов, 
детских яслей и детских садов, усилении уголовного наказания за неплатеж алиментов и о некоторых изменениях в законодательстве о разводах» ${ }^{4}$;

- Указ Президиума Верховного Совета СССР от 8 июля 1944 г. «Об увеличении государственной помощи беременным женщинам, многодетным и одиноким матерям, усилении охраны материнства и детства, об установлении почетного звания «Матьгероиня» и учреждении ордена «Материнская слава» и медали «Медаль материнства» 5 .

В дальнейшем в СССР, а значит, и в России, до 1981 г. меры демографической/семейной политики сводилась к экономической и моральной поддержке многодетности, с 1974 г. была введена также экономическая поддержка малообеспеченных семей (пособие на детей в семьях с доходом менее 50 руб. на человека выплачивалось до исполнения ребенку 12 лет), существовали также незначительные пособия для одиноких матерей, еще с 1941 г. существовал налог на бездетность/малодетность ${ }^{6}$, ставка которого периодически пересматривалась, была в некоторые периоды времени разной для разных категорий граждан и к 1980-м годам составляла 6\% заработка, собирали этот налог со всех бездетных мужчин с 18 лет и с бездетных замужних женщин. То есть в сталинскую эпоху, что вполне соответствует ее духу, были введены в основном «отрицательные» меры стимулирования рождений, связанные с запретами и своего рода штрафами, а не с денежным поощрением семей с детьми (за исключением многодетных).

В 1980-е популярной стала идея поощрения среднедетной семьи, поскольку некоторым демографам (Кваша 1981, Антонов 1980) реально достижимым казалось именно простое, а не расширенное воспроизводство населения. Однако в экстенсивной экономике ощущалась и постоянная потребность в новых людях как работниках. Кроме увеличения отпуска по рождению ребенка и введения отпуска по уходу за ним, оплачиваемого до 1 года (с конца 1980-х - до 1,5 лет) и неоплачиваемого до 1,5 лет (с конца 1980-х - до 3 лет), проводилась и пропагандистская кампания, причем в одних регионах говорили о недостатках многодетности, в других - о минусах малодетности.

\section{6. ИЗМЕНЕНИЯ В КОНЦЕПЦИЯХ СЕМЕЙНОЙ ПОЛИТИКИ: СЛУЧАЙ СОЕДИНЕННЫХ ШТАТОВ АМЕРИКИ}

В Соединенных Штатах Америки всегда было сильным, с одной стороны, внимание к индивидуальным правам и потребностям человека, а с другой - представление, согласно которому семья является своего рода бастионом, внутрь которого государство не должно проникать, даже и с добрыми намерениями (Ooms 2019). В связи с этим для концептуальной ситуации в области семейной политики в этой стране характерны противоречивые ценностные ориентиры, отсутствие договоренности между исследователями относительно определения понятия «семейная политика», области ее применения и задач, конфликтность

\footnotetext{
${ }^{4}$ URL: http://base.consultant.ru/cons/ cgi/online.cgi?req=doc;base=ESU;n=4068

${ }^{5}$ URL: http://base.consultant.ru/ cons/cgi/online.cgi?base=ESU\&n=507\&req=doc

6 «О налоге на холостяков, одиноких и бездетных СССР», Указ Президиума Верховного Совета СССР от 21 ноября 1941)г. (Ведомости Верховного Совета CCCP 1941, 42). URL: http://istmat.info/node/24347
} 
и напряжение между акторами в этой области (например, НКО, церкви и др.), а также идеологические противоречия между индивидуализмом и фамилизмом. Благодаря государственной структуре США на национальном уровне во многих уже традиционных областях (таких, как отпуск по уходу за ребенком) семейно-политические программы в этой стране часто отсутствуют, политики отдельных штатов могут быть противоположно направленными (как это происходило недавно с развитием политики в области легального статуса абортов).

Быстрые изменения в семейных структурах и гендерных ролях во второй половине $\mathrm{XX}$ века создают неопределенность и путаницу в отношении того, как политики должны на это отвечать, какой должна быть роль государства, как нужно переводить огромное количество результатов исследований в этой области на язык специальных политик и программ. К тому же в США, по мнению Оомс, существует традиция чрезмерно позитивно изображать всё, что связано с семьей, замалчивать или отрицать противоречия и темные стороны семейной жизни: «На мой взгляд... [есть] тенденция приукрашивать семейные вопросы - всегда описывать семьи слащавыми словами, не справляясь с задачей открытого признания противоречивых чувств, связанных с семьей, и темных сторон семейной жизни.... Может быть, легче избегать дискуссий о семейной политике потому, что они требуют открытого разговора о многочисленных противоречивых и смешанных в эмоциональном отношении явлениях, с которыми некомфортно иметь дело» (Ooms 2019: 20).

Изначально семейная политика в этой стране ассоциировалась исключительно, или в первую очередь, с детьми и их мамами. Дальнейшая эволюция привела к признанию того факта, что любые индивиды (отцы, дедушки, бабушки, братья и сестры, тети и дяди) могут играть важную семейную роль и их надо учитывать, как и тот факт, что не только состоящие в браке пары, но и сожительствующие, а также живущие отдельно и разведенные, в том числе и бездетные, имеют свои специфические интересы. Подчас это конфликтные интересы, что отражено в разнообразии позиций НКО, защищающих права разных сторон. Корни движения за права детей растут из движения «спасения детей» конца XIX века, и для его представителей долго была неприемлемой идея, что в круг интересов надо включать родителей - ведь именно от «плохих родителей» детей и надо было, как правило, спасать.

Движение за права женщин особенно негативно относится к программам, поддерживающим целостность семьи, особенно к таким, которые могут помешать женщинам участвовать в рынке труда или мотивируют их оставаться в отношениях со склонным к насилию или пренебрегающим семейными обязанностями партнером. С другой стороны, группы, в центре внимания которых находится семья в целом, иногда не понимают, что может существовать необходимость защищать интересы детей или супругов от склонных к насилию родителей/партнеров. Однако в США в течение последних десятилетий происходит взаимное движение всех этих направлений друг к другу, они учатся работать вместе и уважать чужие взгляды. В России о таком движении к консенсусу пока приходится только мечтать. Но и в США это непростое движение, различия в подходах к важным вопросам иногда только нарастают (например, все в том же вопросе о легальном статусе аборта). 
В такой ситуации, с точки зрения Оомс, полезна экологическая теория семьи, которая стремится учесть интересы индивидов в контексте их семейных взаимосвязей на разных стадиях формирования семьи и прежде всего в отношении их заботы друг о друге. Такая концептуализация позволяет выявить «слабые места» в области внутрисемейной заботы, те области, в которые обществу имеет смысл вмешаться и помочь семье, при этом в каких-то случаях общественным службам необходимо подменить собой семью, а в какихто - только помочь и поддержать. Важно так концептуализировать основы семейной политики, чтобы получатели помощи являлись не пассивными реципиентами, а полноправными партнерами государства. То есть основной вопрос исследований семейной политики ставится следующим образом: насколько хорошо государственная политика или отдельные программы помогают семьям выполнять свои семейные обязанности - становятся ли помощью или препятствием (Cherlin 1984). А чтобы лучше это понимать, необходимо развивать статистику, собирающую информацию по огромному количеству показателей о различных сторонах семейной жизни, что в США и происходит. Все чаще чиновники перед принятием новой программы семейной политики применяют даже такой заимствованный из медицины метод, как рандомизированное тестирование новой политики с контрольной группой. Например, успешными оказались некоторые программы по предотвращению подростковых беременностей, которые стали затем более широко применяться (Baron 2018).

На федеральном уровне в США давно существуют и развиваются прежде всего программы борьбы с бедностью (эту страну почти все классификации относят к либеральному или англо-саксонскому режиму), в том числе детской и одиноких матерей. Помощь оказывается в виде денежных или товарных пособий нуждающимся родителям, хотя в 1990-е годы были введены временные ограничения на такие пособия, чтобы все-таки стимулировать людей работать (эти пособия можно получать не более чем 2 года непрерывно и не более 5 лет в течение жизни), а также в виде разнообразных налоговых вычетов в связи с наличием детей и со вступлением в брак (США поддерживают зарегистрированный брак с помощью специальной политики). Некоторые штаты дополняют такие программы предоставлением субсидий на оплату ухода за маленькими детьми.

Существуют пока только на уровне отдельных сообществ программы по ответственному отцовству, направленные не на белых беловоротничковых отцов, а на отцов с небольшим доходом, не имеющих права на опеку над детьми, проживающих в городе афроамериканцев. Эти программы учат их обращаться с системой поддержки детей, искать работу, получать родительские навыки. Некоторые такие программы также получают финансирование из федеральных фондов.

Когда-то президент Никсон наложил вето на проект, предлагавший развитие национальной системы развивающих детских садов, в связи с тем, что это противоречило идее невмешательства государства в дела семьи. С тех пор ситуация радикально изменилась. Очень многие матери работают, увеличились субсидии на оплату ухода за детьми, на рынке труда чаще предлагаются гибкие в отношении рабочих часов схемы занятости, государственные и частные работодатели рутинно предоставляют неоплачиваемый отпуск матерям, реже отцам, в связи с рождением ребенка (по акту о 
семейном или медицинском отпуске 1993 г.). Но доступность и качество оплачиваемого ухода за детьми остаются недостаточными, и США остаются единственной развитой страной, не предоставляющей оплачиваемого родительского отпуска на уровне федерального законодательства.

Политика в области предотвращения подростковых беременностей была большой проблемой в начале 1980-х годов, а сейчас эту область можно назвать одной из историй успеха в американской семейной политике. Частота подростковых беременностей начала расти в середине 1970-х вслед за либерализацией добрачного сексуального поведения среди подростков. Исследователи обращали внимание на негативные последствия этого как для матерей, так и для детей. Сексуального просвещения в школах не существовало, а забеременевшим девушкам не давали возможности остаться в школе и завершить образование. Предложения о развитии сексуального образования, распространении контрацепции в школах и предоставлении юным матерям жилья и помощи в получении образования общественность встречала негативно как подрывающие авторитет родителей. В 1996 г. Национальная Кампания по предотвращению подростковых беременностей начала свою деятельность на национальном уровне через медийное воздействие на различные целевые группы (подростки, родители, молодые взрослые), а также через программы на уровне соседских сообществ. Из-за сензитивности темы в программы не были включены политики и госслужащие ни из консервативного, ни из либерального крыла, в коммуникации обходились острые вопросы об абортах, воздержании, и «естественной» контрацепции. И все равно частота подростковых беременностей к 2017 г. упала до уровня 1940 г. во всех штатах и расовых группах.

Политика в области предотвращения насилия над детьми и пренебрежения родительскими обязанностями осуществляется штатами, но финансируется из федерального источника. Это позволяет центральной администрации выделять деньги не только на изъятие детей из семей в сложных случаях, но и на работу с родителями и создание возможностей для их ресоциализации в отношении выполнения ими родительских обязанностей. Для этого проводятся специальные тренинги, недавно принят обновленный Акт о первичности профилактики и помощи семье 2018 г.

Что касается брачности, долгие годы авторы в основном только выражали сожаления в связи с кризисом семьи, ростом числа разводов и нежеланием мужчин и женщин вступать в брак. О том, что делать и надо ли что-то делать, не говорили. В кругах специалистов по семейной политике избегали даже произносить само слово “брак”. Брак, как и семья, не упоминается в американской конституции, отчасти поэтому эта тема не была релевантной для федеральной повестки. Законодательство в области брака и развода - прерогатива штатов, они же определяют законные права и обязанности супругов. На общенациональный уровень дебаты вышли в 1990-е, некоторые увидели в этом попытку вернуть прошлое, реставрировать патриархальные нормы. Другие считали, что брак может эволюционировать, стать более гибким и равноправным институтом, а в случае стабильности брак благоприятен и для детей, и для взрослых. В 1996 г. был принят федеральный Акт о защите брака, который включил в федеральную повестку понятия «брак» и «супруги». Был также принят Акт о персональной ответственности и возможностях трудоустройства, призванный поддерживать создание рабочих мест, 
вступление в брак, создание семьи с двумя родителями, сокращение числа внебрачных рождений. Поддержка семей с двумя родителями на какое-то время стала более существенной по сравнению с помощью одиноким матерям и отцам. На все эти цели отдельным штатам выделялись специальные гранты. Сообщества по борьбе с семейным насилием и по поддержке одиноких матерей начали протестовать против такой системы, поскольку она создавала сложности для одиноких родителей и жертв насилия. Затем программу несколько модифицировали, она стала считаться поддерживающей только «здоровую» семью, всем организациям, получающим гранты, было вменено в обязанность консультирование с местными активистами в области противодействия семейному насилию. По мнению некоторых, движение «за брак» получило такую силу в том числе в результате действий тех, кто стремился легитимизировать однополые браки (в конце 1990-х об этом не могло быть и речи, в 2015 г. был принят легитимизирующий их Акт).

В отличие от того, что в 2019 г. происходило в России, в США все 2000-е годы предпринимались попытки добиться взаимопонимания между организациями разной направленности в области формирования повестки семейной политики: сторонниками «здоровой семьи», «ответственного отцовства» и предотвращения семейного насилия. Проводились совместные семинары, позволяющие лучше узнать друг друга и понять взаимные опасения. В результате возникла некоторая совместная повестка, образовались организации, подобные «Умному браку» Дианы Солли (Ooms 2019), проводятся тренинги на уровне соседских сообществ. Некоторые священники соглашаются заключать браки только при условии, что молодые прошли такие тренинги. Развиваются программы, направленные сразу на два поколения одной семьи.

Наиболее сложным новым вызовом становится семейная забота о стариках и инвалидах. Сейчас в США около $80 \%$ такой заботы лежит на семьях и родственниках. При этом заботящиеся подвергают повышенному риску свое собственное психическое и физическое здоровье, а государство от этой сферы устранено. В целом, по отличному выражению Оомс, в США, несмотря на все, что делается, «семьи волнуют всех, но никто за них не отвечает» (Ooms 2019: 33, пер. автора). Слишком фрагментировано знание о меняющейся семье, не систематизированы институты и меры, целью которых является помощь семьям.

\section{7. ВЫВОДЫ И ЗАКЛЮЧЕНИЕ}

Идеологически семейная политика выросла из двух очень разных концептуальных оснований. С одной стороны, к ней обратились в связи с разочарованием в эффективности политики демографической в надежде, что хотя бы косвенно она может повлиять на рождаемость. С другой стороны, она является частью социальной политики, основной задачей которой является борьба с бедностью. Эта противоречивость оснований часто проявляют себя в кризисные моменты, когда населению может показаться аморальной демографическая сторона политики, поскольку в помощи нуждаются все, независимо от своего родительского статуса (как, например, в начале 2020 г. в период пандемии COVID19). В более спокойное время государство, напротив, стремится очень точечно и 
целенаправленно тратить деньги на семьи, обладающие демографическим потенциалом, ожидая, что от бедности люди смогут защитить себя сами.

С другой стороны, рождаемость может рассматриваться как общественное благо (Demeny 2003) с очень большими оговорками, поскольку на индивидуальном уровне у каждого человека не только разные репродуктивные установки и представления о желаемом числе детей для себя, но и разные взгляды на идеальное число детей, которое в среднем должны иметь люди в его обществе. Совершенно не обязательно усредненное представление людей об этом будет совпадать с величиной простого или «слегка расширенного» воспроизводства населения, к которой так или иначе стремится большинство политиков, разрабатывая демографические программы. Таким образом, большинство людей может воспринимать демографические цели политик, принятых в государстве, как навязанные им, в идеале предпочитая, чтобы их налоги тратились иначе. Государство в той или иной степени отдает себе отчет в этом консенсусе во вверенном ему обществе, может быть, именно поэтому демографические цели политик в последние десятилетия в большинстве стран имплицитны, а не эксплицитны. Показательным примером здесь может служить совершенно разная социально-политическая реакция европейских правительств на ситуацию падения рождаемости в 1930-х и в 1990-2000-х годах. В первом случае казалось однозначным, что рост населения важен и нужен, и были приняты специальные меры для этого. Во втором последующее развитие уже показало, что с вниманием к росту населения может быть связан рост национализма до опасных пределов, а также, что взрывной рост населения в мировых масштабах, пока еще не полностью остановленный, может быть опасен сам по себе.

В связи с этим сейчас многим исследователям и политикам хотелось бы найти инструменты, позволяющие обеспечить воспроизводство населения примерно на уровне простого, а не расширенного или суженного. Но надежные «рычаги», позволяющие управлять поведением людей так, чтобы добиться именно такого состояния, пока не найдены. К тому же в последние десятилетия попытки слишком откровенного манипулирования людьми, в том числе и в этом отношении, вызывают много этических вопросов.

Классификации и типологии систем семейной политики в развитых странах многообразны, и по основаниям для разделения это могут быть разные моральноценностные системы: универсализм, основанный на эгалитарном принципе справедливости, роулсианская система, согласно которой помогать надо только самым бедным, пропорциональная система, когда справедливым представляется распределение благ в соответствии с предшествующим вкладом в общее дело; гендерные и возрастные аспекты - людям какого возраста и пола считается более правильным оказывать помощь и какую; оправданно ли помогать семье услугами, замещающими семейную заботу, или они ведут к дальнейшему распаду семейного единства и лучше помогать деньгами, а непосредственную заботу пусть осуществляют члены семьи сами и многое другое (Gauthier 2002).

Очень важным оказывается измерение семья - индивид. Его существенным частным случаем становится идеологическое разделение - семья или семьи, поскольку в настоящее 
время существует множество разных форм семьи. Исторически в каком-то смысле, с точки зрения предъявляемых прав на человека, семья и государство являются в некотором роде конкурирующими институтами. О кризисе семьи начали говорить практически с того момента, когда начала распадаться большая многопоколенная семья; с тех пор дробление постоянно усугублялось, на нуклеарной семье «распад» не остановился. Сейчас есть множество вариантов семей родителей-одиночек или бездетных партнеров-супругов, другие варианты. Изначально права и власть главы семьи над остальными ее членами были гораздо большими, чем сейчас; часть этих прав государство отняло еще на самом раннем этапе, одновременно постепенно перехватив многие функции семьи, что означало не только помощь, но и власть, право диктовать людям, как им принимать решения. Это произошло, например, в области медицины и особенно образования: детский труд был признан незаконным, школьное образование - обязательным. Одной из последних немногочисленных функций или областей собственно семейной компетенции остается именно рождение, содержание и воспитание детей. Эту задачу государство не готово полностью взять на себя не только в биологическом, но и в финансовом отношении, и с точки зрения вкладываемых в повседневное родительство усилий. Возможно, поэтому именно в этой точке оно вместо того, чтобы очередной раз «перехватить» функции семьи, стало, наоборот, всячески поддерживать семью и даже платить ей. Но «платить» (в том числе, услугами) намного меньше реальных сумм расходов на детей за всё время их роста. При этом государство многих стран предъявляет максимальные права на выросших детей (например, там, где существуют армии с мобилизационной системой). Таким образом, представление, что семья - это бастион, в независимую жизнь которого лучше не вмешиваться, все еще продолжающее существовать в некоторых странах (например, в США), где исторически семья, действительно, была в наименьшей степени затронута как помощью, так и властью, государства, совершенно нерелевантно для большинства других развитых стран. Но и США - модернизированная страна, где очень влиятельна идеология индивидуализма, поэтому определить, нуждаются ли в помощи отдельные индивиды внутри семьи или семья в целом, очень непросто политикам и там (Ooms 2019).

Всё больше стран, где политика народонаселения сливается с семейной политикой, а последняя во все большей степени стремится скорее идти за социальными изменениями (например, учитывать нарастающее разнообразие форм семьи, изменение гендерных ролей, участие всех взрослых в рынке труда и др.), а не пытаться направить людей в заранее заданное русло. Основным концептуальным ожиданием, связанным с рождаемостью, при этом является то, что, если создавать для людей и семей благоприятные условия (такие, которые представляются благоприятными им самим) в процессе осуществления родительских интенций, они родят больше детей, чем если этого не делать. 


\section{ЛИТЕРАТУРА}

Антонов А.И., Медков В.М., Архангельский В.Н. (2002). Демографические прочессы в России ХХІ века. М.: Грааль.

Антонов А.И., Сорокин С.А. (2000). Судьба семьи в России ХХІ века. М.: Грааль.

Бодрова В.В. (1971). Демографические процессы и демографическая политика в социалистических странах Европы. В Д.И. Валентей (Ред.), Марксистко-ленинская теория народонаселения (сс. 391-400). М: Мысль.

Валентей Д.И. (1967). Теория и политика народонаселения. М.: Высшая школа.

Валентей Д.И. (1971). Политика народонаселения. В Д.Л. Бронер, И.Г. Венецкий (Ред.), Проблемы демографии (сс. 12-21). М: Статистика.

Валентей Д.И., Араб-Оглы Э. А. (1985). Демографический энџиклопедический словарь. М.: Советская энциклопедия.

Валентей Д.И., Бурнашев Э.Ю. (Ред.) (1970). Вопросы теории и политики народонаселения. М.: Изд. МГУ.

Гастев А.К. (1972). Как надо работать. М.: Экономика.

Елизаров В.В. (2017). Теория и практика демографической политики в CCCP. Statistics and Economics, 14(5), 71-84.

Захаров С.В. (2006). Демографический анализ эффекта мер семейной политики в России в 1980-х годах. SPERO, 5, 33-69.

Захаров С.В. (Ред.) (2016). Население России 2014: двадияать второй ежегодный демографический доклад. М.: Изд. дом Высшей школы экономики.

Захаров С.В. (Ред.) (2017). Население России 2015: двадияать третий ежегодный демографический доклад. М.: Изд. дом Высшей школы экономики.

Иванюшкин А.Я., Лапин Ю.Е., Смирнов В.И. (2013). Евгеника: от утопии к науке и ... от науки к утопии? Российский педиатрический журнал, 2, 55-59.

Исупова О.Г. (2017). Вспомогательные репродуктивные технологии: новые возможности. Демографическое обозрение, 1, 35-64.

Кваша А.Я. (1981). Демографическая политика в СССР. М: Финансы и статистика.

Кременцов Н.Л. (2014). От «звериной философии» к медицинской генетике: евгеника в России и Советском Союзе. Историко-биологические исследования, 6(2), 24-56.

Лармин О.В. (1975). Методологические проблемы изучения народонаселения. М: Статистика.

Медков В.М. (2002). Демография: Учебное пособие. Ростов-на-Дону: Феникс.

Пискунов В.П., Стешенко В.С. (Ред.) (1974). Демографическая политика. М.: Статистика.

Поппер К. (1992). Открытое общество и его враги. Т. 1 М.: Феникс.

Хайек Ф.А. фон (2005). Дорога к рабству. М.: Новое издательство. Библиотека Фонда «Либеральная миссия».

Anttonen A., Baldock J., Sipilä J. (Eds.) (2003). The Young, The Old and the State. Cheltenham: Edward Elgar. 
Anttonen A., Sipilä J. (1996). European social care services: Is it possible to identify models? Journal of European Social Policy, 2, 87-100.

Bahle Th. (2008). Family policy patterns in the enlarged EU. In J. Alber, T. Fahey, C. Saraceno (Eds.), Handbook of quality of life in the enlarged European Union (pp. 100-126 ). London and New York: Routledge.

Baron J. (2018). A brief history of evidence-based policy. Annals of the American Academy of Political and Social Science, 678, 40-50. https://doi.org/ 10.1177/0002716218770642.

Bashford A., Levine Ph. (Eds.) (2010). The Oxford Handbook on the History of Eugenics. New York: Oxford University Press.

Bettio F., Plantenga J. (2004). Comparing Care Regimes in Europe. Feminist Economics, 10(1), 85-113.

Bradshaw J. (2006). Child Benefit Packages in 15 Countries in 2004. In J. Lewis (Ed.). Children, Changing Families and Welfare States (pp. 26-50). Cheltenham: Edward Elgar.

Broberg G., Roll-Hansen N. (Eds.) (1996). Eugenics and the Welfare State: Sterilization Policy in Denmark, Sweden, Norway, and Finland. East Lansing: Michigan State University Press.

Cherlin A. (1984). Family policy and family professionals. Journal of Family Issues, 5, 155-159.

Daly M. (2011). What Adult Worker Model? A Critical Look at Recent Social Policy Reform in Europe from a Gender and Family Perspective. Social Politics, 18(1), 1-3.

Demeny P. (2003). Population Policy: A Concise Summary. In P. Demeny, G. McNicoll (Eds.). International Encyclopedia of Population. New York: Macmillan Reference. Policy Research Division Working Papers, www.popcouncil.org/publications/wp/prd/rdwplist.html.

Galton F. (1904). Eugenics: Its Definition, Scope and Aims. American Journal of Sociology, $10(1), 1-25$.

Gauthier A.H. (2002). Family policies in industrialized countries: Is there convergence? Population, 57(3), 447-474. DOI: 10.2307/3246635 https://www.persee.fr/doc/pop_16342941_2002_num_57_3_18403

Hantrais L. (2007). Social Policy in the European Union. Red Globe Press. https://doi.org/10.1177/019251384005002001 UK

Kamerman Sh. (2010). Child, family and the state: the relationship between family policy and social protection policy. In Sh. Kamerman, Sh. Phipps, A. Ben-Arieh (Eds.), From Child Welfare to Child Well-Being (pp. 429-437). New York: Springer.

Kamerman Sh., Kahn A.J. (Eds.) (1978). Family policy: Government and Families in Fourteen Countries. New York: Columbia University Press.

Kaufmann F. X. (2002). Politics and policies towards the family in Europe. A framework and an inquiry into their differences and convergences. In F.X. Kaufmann (Ed.), Family Life and Family Policies in Europe. Vol. 2: Problems and Issues in Comparative Perspective (pp. 419-477). Oxford: Clarendon Press.

Korpi W. (2000). Faces of inequality: gender, class and pattern of inequalities in different types of welfare states. Social Politics, 7(2), 127-191.

Kühl S. (2013). For the Betterment of the Race: The Rise and Fall of the International Movement for Eugenics and Racial Hygiene. New York: Palgrave Macmillan.

Leitner S. (2003). Varieties of familialism. The caring function of the family in comparative perspective. European Societies, 5(4), 353-375. 
Lewis J. (1992). Gender and the development of welfare regimes. Journal of European Social policy, 2(3), 159-173.

Lloyd W. F. (1968 [1833]). Two lectures on the checks to population. In Lectures on Population, Value, Poor Laws and Rent. New York: Augustus M. Kelley.

Madeira J.L., (1974). Towards a demographic policy. Notas Poblacion, 2(6), 13-36.

Mills C.R. (1951). White Collar: The American Middle Classes. Oxford University Press.

Ooms T. (2019). The evolution of family policy: Lessons learned, challenges, and hopes for the future. Journal of Family Theory \& Review, 11(1), 18-38. DOI:10.1111/jftr.12316 11: 18-38.

Orloff A.S. (1993). Gender and the social rights of citizenship. The comparative analysis of gender relations and welfare states. American sociological review, 58(3), 308-328.

Saraceno C., Keck W. (2010). Can we identify intergenerational policy regimes in Europe? European Societies, 12(5), 675 - 696.

Stepan N.L. (1996). "The Hour of Eugenics": Race, Gender, and Nation in Latin America. Ithaca: Cornell University Press. 


\title{
POPULATION AND FAMILY POLICY IN DIFFERENT COUNTRIES: CONCEPTUAL APPROACHES AND PRACTICES
}

\author{
OLGA ISUPOVA
}

\begin{abstract}
The article is concerned with the analysis of various conceptual approaches to family and population policy since the formation in the 19th century of the theoretical foundations of the State's impact on the population. Historically, family policy grew out of population policy, and at the same time is a late developed part of social policy. This might explain the large number of contradictions in its ideology in different countries. The article considers the evolution of approaches to family policy in Europe and the United States, with an emphasis on development in the last decades of the 20th and the first decades of the 21 st century (fertility and economic development, children's and women's education, reproductive rights, the well-being of various age and gender groups of the population, work-life balance, the reaction to a drop in the birth rate below the level of simple reproduction, the ethical perception by the population of the "imposition" of fertility standards on people, etc.). Various typologies of family policy systems based on different foundations in developed countries are examined; the diversity in this area indicates a lack of consensus and convergence, while none of the national policy systems can be called unequivocally efficient. An important dimension for determining the ideology of family policy at the present time is whether it is addressed to an individual (and to which individual) or to the family as a community (and to which particular form / forms of the family), and how each specific concept resolves the issue of the family's interaction with the State. Using the example of the United States, it is shown how the idea that it is better not to interfere in family matters gradually changed, so that there appeared not only individual policies to help families, but also a desire to change legislation accordingly. Now, there are more and more countries where family policy is likely to follow social changes, instead of trying to channel them in a predetermined direction.
\end{abstract}

Key words: population policy, family policy, fertility, welfare, family and state.

Olga IsUPOVA (oisupova@hse.ru), NATIONAL RESEARCH UNIVERSITY HigHER SCHOOL OF ECONOMICS, RUSSIA.

THIS ARTICLE IS THE PRODUCT OF A RESEARCH PROJECT IMPLEMENTED AS PART OF THE BASIC RESEARCH PROGRAMME AT THE NATiONAL RESEARCH UNiVERSITY Higher SCHOOl OF ECONOMICS (HSE) 2019.

DATE RECEIVED : MAY 2020.

\section{REFERENCES}

Antonov A.I., Medkov V.M., Arkhangelsky V.N. (2002). Demograficheskie protsessy v Rossii $X X I$ veka [Demographic processes in XXI century Russia]. Moscow: Graal. (In Russ.).

Antonov A.I., Sorokin S.A. (2000). Sud'ba semyi v Rossii XXI veka [Destiny of the Family in XXI century Rusiia]. Moscow: Graal. (In Russ.).

Anttonen A., Baldock J., Sipilä J. (Eds.) (2003). The Young, The Old and the State. Cheltenham: Edward Elgar.

Anttonen A., Sipilä J. (1996). European social care services: Is it possible to identify models? Journal of European Social Policy, 2, 87-100.

Bahle Th. (2008). Family policy patterns in the enlarged EU. In J. Alber, T. Fahey, C. Saraceno (Eds.), Handbook of quality of life in the enlarged European Union (pp. 100-126 ). London and New York: Routledge. 
Baron J. (2018). A brief history of evidence-based policy. Annals of the American Academy of Political and Social Science, 678, 40-50. https://doi.org/ 10.1177/0002716218770642.

Bashford A., Levine Ph. (Eds.) (2010). The Oxford Handbook on the History of Eugenics. New York: Oxford University Press.

Bettio F., Plantenga J. (2004). Comparing Care Regimes in Europe. Feminist Economics, 10(1), 85-113.

Bodrova V.V. (1971). Demograficheskie protsessy I demograficheskaya politika v sotsialisticheskih stranakh Evropy [Demographic processes and demographic policy in Europe's socialist countries]. In Valentey D.I. (Ed.), Marksistsko-leninskaya teoriya narodonaseleniya (pp. 391-400) [Marksist and Leninist population theory]. Moscow: Mysl. (In Russ.).

Bradshaw J. (2006). Child Benefit Packages in 15 Countries in 2004. In J. Lewis (Ed.). Children, Changing Families and Welfare States (pp. 26-50). Cheltenham: Edward Elgar.

Broberg G., Roll-Hansen N. (Eds.) (1996). Eugenics and the Welfare State: Sterilization Policy in Denmark, Sweden, Norway, and Finland. East Lansing: Michigan State University Press.

Cherlin A. (1984). Family policy and family professionals. Journal of Family Issues, 5, 155-159.

Daly M. (2011). What Adult Worker Model? A Critical Look at Recent Social Policy Reform in Europe from a Gender and Family Perspective. Social Politics, 18(1), 1-3.

Demeny P. (2003). Population Policy: A Concise Summary. In P. Demeny, G. McNicoll (Eds.). International Encyclopedia of Population. New York: Macmillan Reference. Policy Research Division Working Papers, www.popcouncil.org/publications/wp/prd/rdwplist.html.

Elizarov V.V. (2017). Teoriya I praktika demograficheskoi politiki v SSSR [Theory and practice of demographic policy in USSR]. Statistics and Economics, 14(5), 71-84. (In Russ.).

Galton F. (1904). Eugenics: Its Definition, Scope and Aims. American Journal of Sociology, $10(1), 1-25$.

Gastev A.K. (1972). Kak nado rabotat' [How one needs to work]. Moscow: Ekonomika. (In Russ.).

Gauthier A.H. (2002). Family policies in industrialized countries: Is there convergence? Population, 57(3), 447-474. DOI: 10.2307/3246635 https://www.persee.fr/doc/pop_16342941_2002_num_57_3_18403

Hantrais L. (2007). Social Policy in the European Union. Red Globe Press. https://doi.org/10.1177/019251384005002001 UK

Hayek F.A. (2005). Doroga k rabstvu [The road to serfdom]. Moscow Novoe izdatelstvo. Library of the foundation «Liberalnaya missiya» [Liberal mission]. (In Russ.).

Isupova O.G. (2017). Vspomogatelnye reproductivnye technologii: novye vozmozhnosti. [Assisted reproductive technologies: new possibilities]. Demographic review, 1, 35-64. (In Russ.).

Ivanushkin A.Ya., Lapin, Yu.E., Smirnov, V.I. (2013). Evgenika: ot utopii k nauke i... ot nauki k utopii? [Eugenics: from utopia to science and... from science to utopia?]. Rossiysky pediatricheskiy journal [Russian pediatric journal], 2, 55-59. (In Russ.).

Kamerman Sh. (2010). Child, family and the state: the relationship between family policy and social protection policy. In Sh. Kamerman, Sh. Phipps, A. Ben-Arieh (Eds.), From Child Welfare to Child Well-Being (pp. 429-437). New York: Springer. 
Kamerman Sh., Kahn A.J. (Eds.) (1978). Family policy: Government and Families in Fourteen Countries. New York: Columbia University Press.

Kaufmann F. X. (2002). Politics and policies towards the family in Europe. A framework and an inquiry into their differences and convergences. In F.X. Kaufmann (Ed.), Family Life and Family Policies in Europe. Vol. 2: Problems and Issues in Comparative Perspective (pp. 419-477). Oxford: Clarendon Press.

Korpi W. (2000). Faces of inequality: gender, class and pattern of inequalities in different types of welfare states. Social Politics, 7(2), 127-191.

Krementsov N.L. (2014). Ot "zverinoy filosofii" k meditsinskoy genetike: evgenika v Rossii I Sovetskom Soyuze [From "beast philosophy" to medical genetics: eugenics in Russia and Soviet Union]. Studies in the History of Biology, 6(2), 24-56. (In Russ.).

Kühl S. (2013). For the Betterment of the Race: The Rise and Fall of the International Movement for Eugenics and Racial Hygiene. New York: Palgrave Macmillan.

Kvasha A.Ya. (1981). Demograficheskaya politika v SSSR [Demographic policy in USSR]. Moscow: Finansy I statistika. (In Russ.).

Larmin O.V. (1975). Metodologicheskie problemy izucheniya narodonaseleniya [Methodological problems of population studies]. Moscow: Statistika. (In Russ.).

Leitner S. (2003). Varieties of familialism. The caring function of the family in comparative perspective. European Societies, 5(4), 353-375.

Lewis J. (1992). Gender and the development of welfare regimes. Journal of European Social policy, 2(3), 159-173.

Lloyd W. F. (1968 [1833]). Two lectures on the checks to population. In Lectures on Population, Value, Poor Laws and Rent. New York: Augustus M. Kelley.

Madeira J.L., (1974). Towards a demographic policy. Notas Poblacion, 2(6), 13-36.

Medkov V.M. (2002). Demografia: uchebnoe posobie [Demography: a schoolbook]. Rostov on Don: Fenix. (In Russ.).

Mills C.R. (1951). White Collar: The American Middle Classes. Oxford University Press.

Ooms T. (2019). The evolution of family policy: Lessons learned, challenges, and hopes for the future. Journal of Family Theory \& Review, 11(1), 18-38. DOI:10.1111/jftr.12316 11: 18-38.

Orloff A.S. (1993). Gender and the social rights of citizenship. The comparative analysis of gender relations and welfare states. American sociological review, 58(3), 308-328.

Piskunov V.P., Steshenko V.S. (Eds.) (1974). Demograficheskaya politika [Demographic policy]. Moscow: Statistika. (In Russ.).

Popper K. (1992). Otkrytoe obshestvo I ego vragi [Open society and its enemies]. Vol. 1. Moscow: Fenix. (In Russ.).

Saraceno C., Keck W. (2010). Can we identify intergenerational policy regimes in Europe? European Societies, 12(5), 675 - 696.

Stepan N.L. (1996). "The Hour of Eugenics": Race, Gender, and Nation in Latin America. Ithaca: Cornell University Press.

Valentey D.I. (1967). Teoriya I politika narodonaseleniya [Theory and policy of population]. Moscow: Vyshaya shkola. (In Russ.). 
Valentey D.I. (1971). Politika narodonaseleniya [Population policy]. In D.L. Broner, I.G. Venetsky (Eds.), Problemy demografii (pp. 12-21). Moscow: Statistika.

Valentey D.I., Arab-Ogly E.A. (1985). Demograficheskiy entsiklopedicheskiy slovar' [Demographic encyclopedic dictionary]. Moscow: Sovetskaya entsiklopediya.

Valentey D.I., Bournashev E.Yu. (Eds.) (1970). Voprosy teorii I politiki narodonaseleniya [Issues of theory and policy of population]. Moscow: Moscow State University edition. (In Russ.).

Zakharov S.V. (2006). Demograficheskyi analyz effekta mer semeinoy politiki v Rossii v 1980kh godakh [Demographic analusis of the effect of measures of Russian family policy in the 1980-s]. SPERO, 5, 33-69. (In Russ.).

Zakharov S.V. (Red.) (2016). Naseleniye Rossii 2014: dvadtsat'vtoroy ezhegodnyy demograficheskiy doklad [Population of Russia 2014: twenty-second annual demographic report]. Moscow: Izdatel'skiy dom Vysshey shkoly ekonomiki. (In Russ.).

Zakharov S.V. (Red.) (2017). Naseleniye Rossii 2015: dvadtsat' tretiy ezhegodnyy demograficheskiy doklad [Population of Russia 2015: twenty-third annual demographic report]. Moscow: Izdatel'skiy dom Vysshey shkoly ekonomiki. (In Russ.). 